\title{
Falske fossiler - flyvefisk og tomhjernede trilobitter
}

Af Niels Hansen, Sydsjcellands Amatørgeologiske Forening

\section{GeologiskNyt nr. 6. december} 2004 var der en artikel om mulige falske fossiler på Ham-burg-messen og andre messer. Jeg har altid haft mine tvivl om mange af tingene, så det var med spænding, jeg ventede på reaktionerne fra allehånde geologer og amatører.

Men intet skete, hvilket undrede mig meget, da tvivlen må have naget hos flere.

\section{Sand og lak}

Jeg havde selv i Kina købt en plade med to Keichosaurer, og jeg havde set de samme plader på messen i Hamburg til mindre formuer, men så står man pludselig i et tempel i Beijing, hvor der er marked, og kan købe en til den rene spotpris. Jeg havde mine tvivl, men vidste ikke rigtigt, hvad jeg skulle mene, men efter artiklen i GeologiskNyt greb jeg præparernålen og brækkede en finger af, og det viste sig nu at fossilet var lavet af lak, hvorpå der var drysset sand - rigtigt flot arbejde.

\section{Flyvefisk}

På stenmessen i Næstved i 2004 havde en

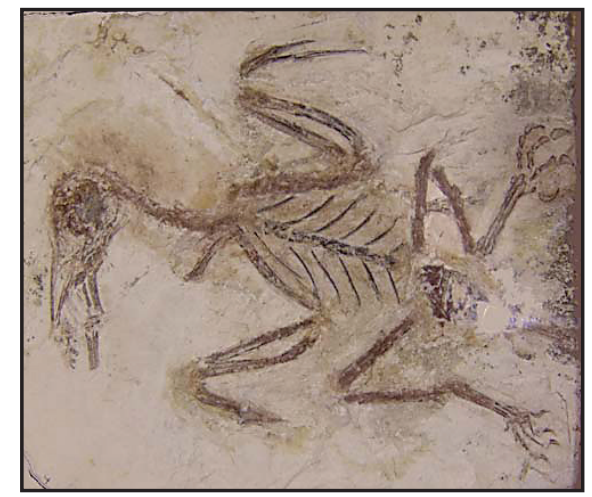

Både fugl og fisk! (Foto: Forfatteren)

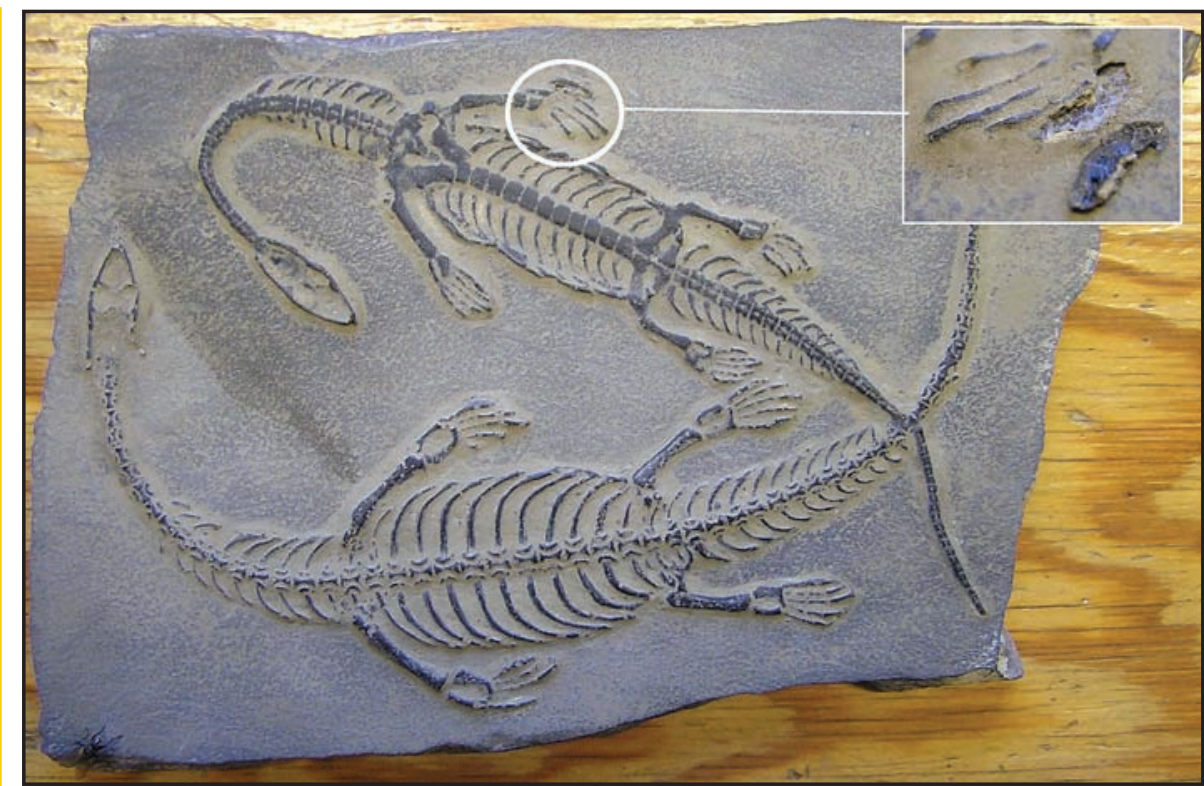

Den “nylakerede” hånd på en Keichosaurus. (Foto: Forfatteren)

udstiller et par kinesiske fugle med som udstilling. Han forklarede stolt, at han havde fået kontakt til en kinesisk fossilhandler, som ad snørklede veje havde fået disse sjældne fossiler ud mod en formidabel "Iøsesum”! Fossilerne var meget flotte og blev beundret af alle.

Nu var det så heldigt, at konservator Steen Lennert Jacobsen fra Geologisk Museum kom ned på messen for at se på nogle andre ting, vi havde, og han ville gerne se nøjere på de fine sager, men ak, efter en tur under mikroskopet kunne han konstatere, at rygraden på den ene fugl var fra en fisk, så såfremt der ikke er tale om verdens ældste flyvefisk, så må vi nok konstatere, at køberen er blevet snydt.

\section{Discount-trilobit}

Et af vore medlemmer havde hos en dansk stenhandler købt en af de store flotte trilobitter til en meget rimelig pris, som skulle bruges til en udstilling. Han var også blevet nysgerrig og begyndte derfor at kradse med en nål og kunne konstatere, at trilobitten var hul! Resolut tog han vinkelsliberen og skar den midt over, og der åbenbarede sig en trilobit støbt i epoxy (efter lugten at dømme).

Han og jeg har moret os godt over vores billige køb, medens andre må føle sig snydt. Men fremover når jeg rejser, vil jeg, hvis prisen er rigtig, indkøbe mystisk udseende fossiler for så at dissekere dem hjemme.

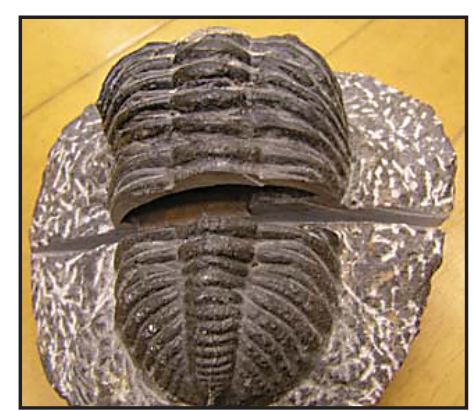

Nu med plads til fyld. (Foto: Forfatteren) 